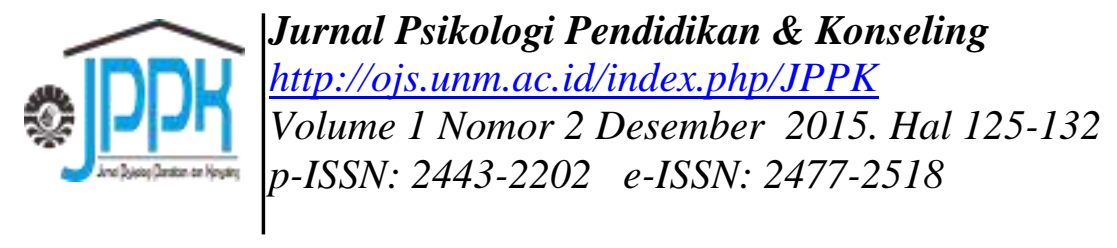

\title{
PENERAPAN KONSELING KELOMPOK REALITAS UNTUK MENINGKATKAN KEMANDIRIAN BELAJAR SISWA SMK NEGERI 3 MAKASSAR
}

\author{
Nasratul Khumaerah \\ Bimbingan dan Konseling, STIKIP Megarezky \\ email: nacha_cute@yahoo.co.id
}

\begin{abstract}
Pre-Experimental research was conducted in SMK Negeri 3 Makassar with research subjects are students of class XI electricity with a total of 10 people. Problems in this study were students in class XI Electricity experiencing a low learning independence. This study aims to: (1) Determine the description of the independence of student learning before the Implementation Group Counseling Reality in SMK Negeri 3 Makassar (2) Knowing illustration independence student learning after Application of Group Counseling Reality in SMK Negeri 3 Makassar (3) Find out if there is a positive impact on Group Counselling Reality application to increase the independence of student learning in SMK Negeri 3 Makassar. Experimental subjects were given a pretest to determine the atmosphere of learning independence given counseling students before reality. At the end of the study were given a posttest to determine the effect of applying the reality of group counseling in improving learning independence. Collecting data using questionnaires and observation. Analyzed using percentages and inferential statistical analysis, the t-test. The results showed that: (1) Independence learn student at SMK Negeri 3 Makassar before the given technique Group Counseling Reality in middle category, while the degree of independence for students at SMK Negeri 3 Makassar after given Engineering Group Counseling Reality has increased or at high category , (2) There are differences in the level of independent learning in SMK Negeri 3 Makassar before and after given the reality of group counseling techniques.
\end{abstract}

Keywords: . The Reality of Group Counseling, Independent Learning.

\begin{abstract}
Abstrak: Penelitian Pre-Eksperimen ini dilakukan di SMK Negeri 3 Makassar dengan subjek penelitian adalah siswa kelas XI Listrik dengan jumlah 10 orang. Masalah dalam penelitian ini adalah siswa di kelas XI Listrik mengalami kemandirian belajar yang rendah. Penelitian ini bertujuan untuk: (1) Mengetahui gambaran kemandirian belajar siswa sebelum Penerapan Konseling Kelompok Realitas di SMK Negeri 3 Makassar (2)Mengetahui gambaran kemandirian belajar siswa sesudah Penerapan Konseling Kelompok Realitas di SMK Negeri 3 Makassar (3) Mengetahui apakah ada pengaruh positif terhadap penerapan Konseling Kelompok Realitas untuk meningkatkan kemandirian belajar siswa di SMK Negeri 3 Makassar. Subjek eksperimen diberi pretest untuk mengetahui suasana kemandirian belajar siswa sebelum diberikan konseling realitas. Di akhir penelitian ini diberi posttest untuk mengetahui pengaruh penerapan konseling kelompok realitas dalam meningkatkan kemandirian belajar. Pengumpulan data dengan menggunakan instrumen angket dan observasi. Analisis data menggunakan analisis persentase dan analisis statistik inferensial, yaitu t-test. Hasil penelitian menunjukkan bahwa: (1) Kemandirian belajar siswa di SMK Negeri 3 Makassar sebelum diberi teknik Konseling Kelompok Realitas berada pada kategori sedang, sedangkan tingkat kemandirian belajar siswa di SMK Negeri 3 Makassar sesudah diberi Teknik Konseling Kelompok Realitas mengalami peningkatan atau berada pada kategori tinggi.
\end{abstract}


(2) Terdapat perbedaan tingkat kemandirian belajar di SMK Negeri 3 Makassar sebelum dan sesudah diberi teknik Konseling Kelompok Realitas.

Kata Kunci: Konseling Kelompok Realitas, Kemandirian Belajar.

\section{PENDAHULUAN}

Pendidikan merupakan proses belajar yang menghasilkan perubahan tingkah laku yang diharapkan. Tugas utama siswa di sekolah adalah belajar, dengan belajar siswa akan berkembang secara optimal sesuai dengan kemampuannya. Pendidikan secara keseluruhan adalah suatu usaha yang disengaja untuk mempersiapkan para peserta didik berkembang secara optimal, siap melaksanakan peranannya di masa yang akan datang.

Di dalam bangku sekolah siswa dituntut untuk lebih mandiri. Untuk itu Sekolah Menengah Atas diharapkan mampu mengembangkan sikap mandiri bagi siswanya, sehingga tidak canggung dalam menapaki bangku kuliah. Kemandirian akan membentuk rasa percaya diri, berani, tanggung jawab, dan kreatif pada diri siswa. Kemandirian belajar merupakan hal yang integral dari keseluruhan proses belajar. Berhasil tidaknya siswa dalam belajar sering kali dapat terlihat pada apakah siswa tersebut memiliki kemandirian belajar atau tidak. Siswa dikatakan telah memiliki kemandirian belajar apabila ia telah mampu melakukan tugas belajar tanpa ketergantungan pada orang lain dan bertanggung jawab atas pilihannya.

Kemandirian belajar merupakan aktifitas belajar yang didorong oleh kemauan sendiri, pilihan sendiri, dan mampu mengatur diri untuk mencapai hasil belajar yang optimal serta mampu mempertanggung jawabkan tindakannya. Siswa dapat dikatakan memiliki kemandirian belajar jika memiliki ciri-ciri di antaranya; mampu berpikir kritis, kreatif dan inovatif, tidak mudah terpengaruh oleh pendapat orang lain, tidak merasa rendah diri, terus bekerja dengan penuh ketekunan dan kedisiplinan, serta mampu mempertanggungjawabkan tindakannya sendiri.

Kenyataan yang banyak di lapangan dari hasil penelitian Rina Aristiani seperti di SMA Negeri 15 Semarang, menunjukkan kurang lebih 100 siswa dari 315 siswa memiliki kemandirian belajar yang rendah. Rina Aristiani, 2006. Keefektifan Layanan Bimbingan Kelompok Dalam Meningkatkan Kemandirian Belajar Siswa Kelas X Sma Negeri 15 Semarang tahun ajaran 2005-2006. Skripsi. Semarang: Unnes. Kerap kali siswa belajar, sekalipun dalam mengambil azas manfaat masih bersikap sebagai anak kecil. Mereka sering bertanya kepada bapak dan ibu guru ketika pelajaran sedang berlangsung, mengenai pelajaran yang ditulis pada papan tulis apakah untuk disalin di buku atau tidak. Sementara jika siswa merasa ada manfaat bagi mereka harus menyalinnya. Dalam membaca buku-buku pelajaran saja misalnya, jika tidak disuruh atau diperintahkan oleh guru maka buku-buku tersebut akan tetap tidak tersentuh dan akan selalu utuh karena tidak dibaca. Begitu pula dalam mengomentari keberadaan buku-buku pelajaran mereka yang jarang mereka sentuh. Mereka menjawab bahwa kalau guru tidak menyuruh untuk mengerjakan tugas-tugas rumah atau untuk membacanya tidak perlu dibaca. Kemandirian dalam belajar agaknya belum dimiliki oleh banyak pelajar. Ada guru yang mengatakan bahwa pelajar sekarang banyak yang bersifat seperti 'paku', ia baru bergerak jika dipukul dengan martil. Terlihat kecenderungan bahwa konsep mereka belajar yaitu "baru berbuat kalau baru disuruh". Jadi kalau mereka tidak disuruh maka tentu agak terhentilah proses peningkatan pengembangan pribadi mereka.

Berdasarkan hasil wawancara bersama konselor di sekolah pada tanggal 13 april 2010 di peroleh info, fakta di atas dimiliki oleh siswasiswa di SMK Negeri 3 Makassar. Banyak siswa yang masih bersifat pasif dalam belajar. Hal ini terlihat ketika beberapa siswa masih ada ketergantungan kepada temannya dalam menghadapi masalah belajar, disiplin belajar masih kurang, kurang mengetahui cara belajar yang baik yaitu belajar kalau akan menjelang ujian, malas dalam mengerjakan tugas-tugas yang telah diberikan oleh guru, masih adanya paksaan untuk belajar dari guru, sering 
menyontek hasil pekerjaan temannya, menghindari masalah dalam, tidak bertanggung jawab atas pilihan yang di ambil, dan mengerjakan tugas pekerjaan rumah saat mengikuti mata pelajaran yang lain yang mengakibatkan proses belajar mengajar menjadi terganggu.

Sehubungan dengan hal tersebut, maka perlu upaya dari guru pembimbing untuk mengatasi atau mengantisipasi terjadinya kurangnya kemandirian belajar siswa. Salah satu upaya tersebut adalah menerapkan konseling kelompok realitas yang dimana dalam penerapannya konseling realitas digunakan dalam konseling kelompok. Teknik ini dalam penerapannya konselor membantu konseli dalam menyelesaikan masalah yang dihadapi tanpa melihat kegagalan yang lalu, tetapi konselor akan menekankan tanggung jawab kepada konseli terhadap pilihan yang akan di pilih untuk mencapai identitas keberhasilan. Dengan harapan melalui penerapan ini dapat meningkatkan kemandirian belajar siswa.

Melihat fenomena-fenomena di atas, maka penulis tertarik untuk mengkaji dan mengetahui bagaimana tingkat kemandirian belajar siswa tersebut. Salah satu cara yang akan digunakan untuk mengatasi permasalahan tersebut adalah dengan menerapkan Konseling Kelompok Realitas.

Rumusan Masalah

1. Bagaimana gambaran kemandirian belajar siswa sebelum penerapan Konseling Kelompok Realitas di SMK NEGERI 3 Makassar?

2. Bagaimana gambaran kemandirian belajar siswa sesudah Penerapan Konseling Kelompok Realitas di SMK NEGERI 3 Makassar?

3. Apakah ada pengaruh positif terhadap Penerapan Konseling Kelompok Realitas untuk meningkatkan kemandirian belajar siswa di SMK NEGERI 3 Makassar?

\section{METODE}

Penelitian yang digunakan oleh peneliti adalah pendekatan kuantitatif dengan metode penelitian eksperimen.

Dalam penelitian ini, peneliti menggunakan pre-eksperimental design karena hanya ada satu kelompok eksperimen tanpa adanya kelompok kontrol. yang akan mengkaji pengaruh konseling kelompok realitas untuk meningkatkan kemandirian belajar siswa di SMK Negeri 3 Makassar. Desain penelitian yang digunakan adalah " one-group pretest-posttest design"

Prosedur pelaksanaan penelitian mulai dari tahap perencanaan, pretest, pemberian konseling kelompok realitas dan posttest.

Dalam penelitian ini ada dua peubah yang dikaji, yaitu: Penggunaan Konseling kelompok realitas untuk meningkatkan kemandirian belajar. Konseling Kelompok Realitas sebagai peubah bebas atau yang mempengaruhi (independen) sedangkan kemandirian belajar sebagai peubah terikat atau yang dipengaruhi (dependen). Untuk lebih memahami dengan jelas variabel yang digunakan dalam penelitian ini, maka perlu diberikan defenisi operasional, yaitu sebagai berikut:

1. Konseling Kelompok Realitas merupakan bentuk konseling yang difokuskan pada tingkah laku sekarang, bentuk bantuan langsung kepada konseli secara kelompok, yang dilakukan oleh konselor dengan cara memberi tanggung jawab kepada konseli yang didasarkan pada keyakinan bahwa kita semua memilih apa yang kita lakukan dengan hidup kita dan kita bertanggung jawab untuk pilihan kita. Tanggung Jawab didefinisikan sebagai pembelajaran untuk memilih perilaku yang memenuhi kebutuhan kita dan, pada saat yang sama, tidak menghilangkan kesempatan orang lain melakukan hal yang sama. Memecahkan masalah-masalah individu sehingga individu dapat merancang alternatif pemecahan yang tepat dalam mengatasi masalah kemandirian dalam belajar.

2. Kemandirian belajar adalah aktivitas belajar yang didorong oleh kemauan sendiri, pilihan sendiri, dan mengatur diri untuk mencapai hasil belajar yang optimal serta mampu mempertanggungjawabkan tindakannya. Cirinya adalah mampu berpikir kritis, kreatif dan inovatif, tidak berpengaruh pada orang lain, tidak lari / menghindari masalah, memecahkan masalah sendiri tanpa bantuan orang lain, berusaha bekerja dengan penuh ketekunan dan bertanggungjawab atas tindakannya sendiri.

Populasi adalah sebagian dari jumlah dan karakteristik yang dimiliki oleh populasi. Bila 
populasi besar dan peneliti tidak mungkin mempelajari semua yang ada pada populasi, misalnya karena keterbatasan dana, tenaga dan waktu, maka peneliti dapat menggunakan sampel yang diambil dari populasi itu.

Siswa yang akan dijadikan sampel diambil dengan mengukur kemandirian belajar dengan angket kemandirian belajar. Sampel yang diambil dalam penelitian ini adalah sebanyak satu kelas yang terdiri atas 30 siswa. Kelas yang dijadikan sampel yaitu KELAS XI Listrik 1. Alasan penelitian ini mengambil sampel di KELAS XI Listrik 1 di SMK NEG. 3 Makassar karena menurut pengamatan guru pembimbing dan wali kelas di sekolah tersebut, sejak dari kelas X kelas ini merupakan kelas yang siswasiswanya cenderung mengalami permasalahan dalam sikap dan perilakunya dalam belajar salah satunya dalam kemandirian belajar.

Pengukuran sampel merupakan suatu langkah yang diambil dalam melaksanakan suatu penelitian. Dari jumlah siswa yang teridentifikasi diambil sebanyak 10 (sepuluh) siswa (jumlah anggota terbatas dalam konseling kelompok ) yang menjadi subjek penelitian. Dengan pertimbangan, dinamika interaksi kelompok akan berkembang lebih intensif dan untuk keefektifan pelaksanaan konseling kelompok realitas.

\section{Teknik Pengumpulan Data}

\section{Observasi}

Observasi yang digunakan mencatat reaksi-reaksi dan partisipasi siswa selama pemberian Konseling Kelompok Realitas melalui pengamatan secara langsung. Cara penggunaannya dengan cara memberi tanda $(\sqrt{ })$ pada setiap aspek partisipasi siswa yang muncul.

2. Angket (Kuesioner)

Kuesioner merupakan teknik pengumpulan data yang dilakukan dengan cara memberi seperangkat pernyataan tertulis kepada respon untuk dijawabkan. Kuesioner dibuat oleh peneliti yang isinya menyangkut Kemandirian belajar siswa. Kuesioner yang digunakan kepada responden peneliti dimana angket peneliti yang sifatnya tertutup, yang terdiri dari item positif dan item negatif beserta dilengkapi dengan lima pilihan jawaban yaitu : Sangat Tidak Sesuai (STS), Tidak Sesuai (TS), Kurang Sesuai (KS), Sesuai (S), Sangat Sesuai (SS). Untuk item positif penilaian pilihan jawaban Sangat Tidak Sesuai $($ STS $)=1$, Tidak Sesuai $($ TS $)=2$, Kurang Sesuai $(\mathrm{KS})=3$, Sesuai $(\mathrm{S})=4$ dan
Sangat Sesuai $(\mathrm{SS})=5$, sedangkan item negatif penilaian pilihan jawaban Sangat Tidak Sesuai $(\mathrm{STS})=5$, Tidak Sesuai $(\mathrm{TS})=4$, Kurang Sesuai $(\mathrm{KS})=3$, Sesuai $(\mathrm{S})=2$ dan Sangat Sesuai $(\mathrm{SS})$ $=1$

Seseuai dengan teknik pengumpulan data yang dilakukan dalam penelitian ini yaitu observasi dan angket (kuesioner) yang telah divalidasi dan diuji lapangan untuk mengetahui validitasi dan reabilitasnya.

a. Uji Validitas

Dari hasil uji validitas skala dengan menggunakan pengolahan komputer program SPSS 16,0 ditemukan bahwa dari 58 item pernyataan, yang tidak valid sebanyak 16 item disebabkan nilai $\mathrm{r}$ yang diperoleh < (lebih kecil atau kurang) dari 0.3 seperti yang dikemukakan oleh Sugiono dan Wibowo (2004) dalam Sujianto (2009), yaitu nomor $(0,069)$, nomor $10(0,101)$, nomor $18(0,194), 19(0,259)$, dan $23(0,275)$, nomor $26(0,463)$, nomor 30 ( $0,056)$, nomor $33(0,452)$, nomor $34(0,264)$, nomor $35(0,198)$, nomor $39(0,043)$, nomor $41(0,283)$, nomor $43(0,018)$, nomor $43(0,0224)$, nomor 53(0,050), nomor 56 $(0,036)$. Sehingga jumlah skala setelah uji validitas sebanyak 42 item pernyataan.

b. Uji Realibilitas

Suatu alat ukur dikatakan memiliki realibilitas yang baik bilamana alat ukur tersebut dapat memberikan skor yang relatif sama pada seorang responden, jika responden tersebut mengisi angket pada waktu yang tidak bersamaan atau pada tempat yang berbeda, walaupun harus memperhatikan adanya aspek persamaan karakteristik. Dalam penentuan tingkat realibilitas suatu instrumen penelitian dapat diterima bila memiliki koefisien alpha lebih besar dari 0,60 sesuai yang dikemukakan oleh Nugroho (2005) dan Suyuthi (2005) dalam Sujianto (2009). Sehingga instrumen penelitian ini dikatakan realibel karena memeiliki koefisien alpha $>0,60$ yaitu sebesar 0,917 .

Analisis data penelitian dimaksudkan untuk menganalisis data hasil angket berkaitan dengan kemandirian belajar siswa, teknik analisis data yang digunakan adalah analisis deskriftif dan uji Wilcoxon.

1. Analisis Statistik Deskriftif

Analisis statistik deskriftif dimaksudkan untuk mengambarkan kemandirian belajar siswa SMK Negeri 3 Makassar sebelum dan sesudah 
perlakuan berupa pemberian konseling kelompok realitas, dengan menggunakan tabel distribusi frekuensi dan persentase

Guna memperoleh gambaran umum tentang kemandirian belajar siswa di SMK Negeri 3 Makassar sebelum dan sesudah perlakuan teknik konseling kelompok realitas, maka untuk keperluan tersebut, maka dilakukan perhitungan rata-rata skor peubah dengan rumus:

$$
M e=\frac{\sum X i}{N}
$$

Di mana:

$$
\begin{array}{ll}
\text { Me } & \text { : Mean (rata-rata) } \\
\mathrm{Xi} & \text { : Nilai X ke i sampai ke n } \\
\mathrm{N} & \text { : Banyaknya subjek }
\end{array}
$$

Guna memperoleh gambaran umum tentang kemandirian siswa dalam belajar di SMK Negeri 3 Makassar sebelum dan sesudah perlakuan, dilakukan dengan mengetahui skor ideal tertinggi $290(58 \times 5=290)$ kemudian dikurangkan dengan skor ideal terendah yaitu 58 ( $58 \times 1=58)$, selanjutnya dibagi 5 kelas interval sehingga diperoleh interval kelas.

2. uji Wilcoxon

"Analisis data merupakan bagian yang teramat penting dalam penelitian, karena dengan analisis data maka akan dapat membuktikan hipotesis dan menarik tentang masalah yang akan diteliti. Dalam penelitian ini pengambilan sampelnya menggunakan teknik cluster bertujuan sehingga tidak dapat menggunakan statistik parametrik tetapi menggunakan statistik non parametrik berupa uji Wilcoxon, dan skala yang dipakai berupa skala bertingkat. Adapun rumus yang digunakan adalah sebagai berikut:
Rumus uji Wilcoxon (Sugiyono, 1996:133)

$$
Z=\frac{T-\mu_{T}}{\sigma T}=\frac{T-\frac{n(n+1)}{4}}{\sqrt{\frac{n(n+1)(2 n+1)}{24}}}
$$

Dari hasil hitung tersebut dikonsultasikan dengan indeks tabel wilcoxon. Jika hasil analisis lebih besar dari indeks tabel wilcoxon, maka berarti konseling kelompok realitas efektif untuk meningkatkan kemandirian belajar.

\section{HASIL DAN PEMBAHASAN}

Berdasarkan hasil penelitian dengan menggunakan Pre-eksperimen yang dilakukan terhadap 10 siswa secara kelompok mengenai kemandirian dalam belajar di SMK Negeri 3 Makassar sebelum dan sesudah perlakuan berupa teknik konseling kelompok realitas, maka berikut ini akan dianalisis dengan menggunakan analisis statistik deskriptif untuk menggambarkan tingkat kemandirian dalam belajar siswa sebelum (pretest) dan setelah (posttest) diberi perlakuan teknik konseling kelompok realitas, dan analisis kuantitatif untuk menguji hipotesis pada penelitian tentang adanya perbedaan tingkat kemandirian dalam belajar siswa sebelum dan setelah diberi perlakuan berupa konseling kelompok realitas. Berikut di jelaskan gambaran tingkat kemandirian belajar siswa sebelum dan sesuadah pemberian konseling kelompok realitas.

1. Gambaran Tingkat Kemandirian dalam Belajar Siswa Sebelum Dan Setelah Diberikan Konseling Kelompok Realitas

Tabel 4.1: Data Tingkat Kemandirian Belajar Siswa Sebelum (Pretest) Dan Setelah (Posttest) Diberikan Konseling Kelompok Realitas di SMK Negeri 3 Makassar.

\begin{tabular}{|l|l|l|c|c|c|}
\hline \multirow{2}{*}{ Interval } & \multirow{2}{*}{ Kategori } & \multicolumn{2}{|c|}{ Pretest } & \multicolumn{2}{c|}{ Posttest } \\
\cline { 3 - 6 } & & Frekuensi & Persentasi & Frekuensi & Persentasi \\
\hline $\mathbf{2 4 4}-\mathbf{2 9 0}$ & Sangat tinggi & 0 & $0 \%$ & 0 & $0 \%$ \\
\hline $\mathbf{1 9 8}-\mathbf{2 4 3}$ & Tinggi & 0 & $0 \%$ & 5 & $50 \%$ \\
\hline $\mathbf{1 5 2}-\mathbf{1 9 7}$ & Sedang & 6 & $60 \%$ & 3 & $30 \%$ \\
\hline $\mathbf{1 0 6}-\mathbf{1 5 1}$ & Rendah & 4 & $40 \%$ & 2 & $20 \%$ \\
\hline $\mathbf{5 8}-\mathbf{1 0 5}$ & Sangat rendah & 0 & $0 \%$ & 0 & $0 \%$ \\
\hline \multicolumn{2}{|c|}{ Jumlah } & 10 & $\mathbf{1 0 0 \%}$ & $\mathbf{1 0}$ & $\mathbf{1 0 0 \%}$ \\
\hline
\end{tabular}

Sumber : Hasil Angket Penelitian

Tabel di atas menunjukkan bahwa sebelum diberikan perlakuan berupa konseling kelompok realitas, tingkat kemandirian belajar siswa di SMK Negeri 3 Makassar, yaitu sebanyak 6 
responden ( $60 \%$ ) berada pada kategori sedang, kemudian kategori rendah sebanyak 4 responden $(40 \%)$. Hal ini berarti bahwa tingkat kemandirian belajar siswa di SMK Negeri 3 Makasssar berada pada kategori sedang.

Setelah diberikan teknik konseling kelompok realitas sebanyak 6 sesi, tingkat kemandirian dalam belajar siswa di SMK Negeri 3 Makassar mengalami peningkatan. Hal ini dapat dilihat dari tingkat kemandirian belajar siswa yang berada dalam kategori rendah 2 responden (20\%), kategori sedang 3 responden $(30 \%)$, dan kategori tinggi sebanyak 5 responden $(50 \%)$.

\section{Pengujian Hipotesis}

Hipotesis penelitian ini adalah "Terdapat pengaruh yang positif terhadap penerapan konseling kelompok realitas untuk meningkatkan kemandirian belajar siswa di SMK Negeri 3 Makassar". Untuk pengujian hipotesis di atas, terlebih dahulu disajikan data tingkat kemandirian belajar siswa, baik pretest dan posttest. Untuk mengetahui signifikansi perbedaan tingkat kemandirian belajar siswa sebelum dan sesudah diberikan konseling kelompok realitas digunakan uji statistik non parametrik Wilcoxon Signed Rank Test. Uji Wilcoxon (Z) ini merupakan uji beda parametrik rata-rata untuk dua sampel berpasangan. Berdasarkan uji statistik tersebut, dilihat dari perbedaan skor tingkat kemandirian belajar siswa sebelum dan sesudah pemberian Konseling kelompok realitas, diperoleh perhitungan $\mathrm{Z}$ dimana nilai statistik uji $\mathrm{Z}$ yang kecil yaitu 2,803 dan nilai sign.2-talled adalah $0,005<0,05$. Sehingga $\pi .0$ di tolak. Karena itu hasil uji tersebut secara statistik, dapat diakatakan Hipotesis penelitian ini adalah "Terdapat pengaruh kemandirian belajar siswa sesudah mengikuti Konseling kelompok realitas.

\section{Pembahasan}

Kemandirian belajar (Self Regulated Learning) merupakan Kemandirian belajar sangat penting bagi seorang siswa, kemampuan belajar sendiri yang dimiliki oleh setiap siswa dengan berbagai macam teknik yang digunakan sesuai dengan keinginannya sendiri dan bertanggung jawab atas pengambilan keputusan yang telah dipilihnya sendiri. Kemandirian belajar pada dasarnya dipengruhi beberapa faktor antara lain gen atau keturunan orang tua, pola asuh orang tua, sistem pendidikan disekolah dan sistem pendidikan di masyarakat.

Schunk dan Zimmerman (1998) mendefinisikan Kemandirian belajar sebagai proses belajar yang terjadi karena pengaruh dari pemikiran, perasaan, strategi, dan perilaku sendiri yang berorientasi pada pencapaian tujuan. Butler (2002) mengemukakan bahwa Kemandirian belajar SRL (Self regulated Learning) merupakan siklus kegiatan kognitif yang rekursif (berulang-ulang) yang memuat kegiatan: menganalisis tugas; memilih, mengadopsi, atau menemukan pendekatan strategi untuk mencapai tujuan tugas; dan memantau hasil dari strategi yang telah dilaksanakan.

Dengan demikian kemandirian dalam belajar menarik dan actual untuk dikaji karena kemandirian belajar merupakan hal yang integral dari keseluruhan proses belajar, berhasil tidaknya siswa dalam belajar sering kali dapat terlihat pada apakah siswa tersebut memiliki kemandirian belajar atau tidak. Siswa dikatakan telah memiliki kemandirian belajar apabila ia telah mampu melakukan tugas belajar tanpa ketergantungan pada orang lain.

Berdasarkan hasil penelitian terhadap 10 subjek penelitian menunjukkan bahwa tingkat kemandirian belajar sebelum diberikan teknik konseling kelompok realitas berada pada kategori rendah. Adapun gejala rendahnya kemandirian belajar yang dialami oleh siswa di SMK Negeri 3 Makassar adalah siswa kurang mampu untuk mandiri dalam belajar, banyak bersifat serba pasif. Dalam membaca buku-buku pelajaran saja misalnya, kalau tidak disuruh atau diperintahkan oleh guru maka buku-buku tersebut akan tetap tidak tersentuh dan akan selalu utuh karena tidak dibaca.

Rendahnya kemandirian belajar siswa merupakan suatu permasalahan yang membutuhkan perhatian ekstra untuk segera diatasi agar mereka dapat menentukan pilihan, dan bertanggung jawab atas pilihannya sesuai potensi yang dimiliki, sehingga mereka dapat memperoleh pencapaian kemandirian belajar yang maksimal. Salah satu teknik yang dapat digunakan untuk membantu kurangnya kemandirian belajar siswa adalah dengan teknik konseling kelompok realitas.

Dengan melihat sumber rendahnya kemandirian belajar siswa di SMK Negeri 3 
Makassar berasal dari masih kurang mampunya siswa untuk merencanakan, memilih dan bertanggung jawab atas pilihannya, maka dengan memberikan teknik konseling kelompok realitas untuk mengintervensi rendahnnya kemandirian belajar siswa. Ini berarti bahwa dengan menekankan tanggung jawab kepada konseli, akan meningkatkan akan kemampuan yang dimiliki, sehingga mampu menentukan pilihan dengan yakin dan siap terhadap resiko yang akan dialami dalam menjalani pilihannya.

Landasan pelaksanaan konseling realitas adalah mencoba membantu mengendalikan dunia di sekitar mereka dengan lebih efektif sehingga mereka lebih mampu memenuhi kebutuhan mereka. Konseling Realitas berprinsip seseorang dapat dengan penuh optimis menerima bantuan dari konselor untuk memenuhi kebutuhankebutuhan dasarnya dan mampu menghadapi kenyataan tanpa merugikan siapapun. Konseling Realitas lebih menekankan masa kini, maka dalam memberikan bantuan tidak perlu melacak sejauh mungkin pada masa lalunya, sehingga yang paling dipentingkan adalah bagaimana konseli dapat memperoleh kesuksesan pada masa yang akan datang.

Pada akhir penelitian atau sesudah pemberian perlakuan, ditemukan perbedaan sebelum dan setelah penerapan konseling kelompok realitas. Dalam hal ini peningkatan skor rata-rata dari sangat rendah, rendah dan sedang ke yang tinggi mengindikasikan adanya pengaruh signifikan dan positif dari perlakuan yang diterapkan mengenai kemandirian belajar siswa.

Berdasarkan hasil penelitian di atas, maka teknik konseling kelompok realitas mampu meningkatkan kemandirian belajar siswa. Di mana dalam penelitian ini siswa diharapkan untuk tidak lagi terpengaruh dengan pendapat orang lain. Siswa menjadi lebih percaya akan kemampuan dan potensi yang dimilikinya, tidak lagi merasa ragu dengan pilihannya dan mampu mempertanggung jawabkan pilihan yang dipilihnya. Diharapkan pula agar siswa mampu menghadapi setiap tantangan yang diperoleh dalam usaha mengembangkan kemandiriannya dan mampu bangkit kembali dari keterpurukanketerpurukan, serta tidak cepat berputus asa dari kegagalan tersebut. dengan demikian siswa akan mampu berkembang dengan optimal dan dapat mencapai cita-citanya kelak di masa depan.

\section{SIMPULAN DAN SARAN}

Berdasarkan hasil dan pembahasan penelitian ini maka dapat disimpulkan bahawa: 1) Tingkat kemandirian dalam belajar siswa di SMK Negeri 3 Makassar sebelum diberikan perlakuan berupa teknik konseling kelompok realitas berada dalam kategori sedang., 2) Setelah diberikan perlakuan berupa teknik konseling kelompok realitas tingkat kemandirian dalam belajar siswa di SMK Negeri 3 Makassar berada pada kategori tinggi. 3) Konseling kelompok realitas berpengaruh positif yang signifikan dalam meningkatnya kemandirian dalam belajar siswa, sehingga terjadi peningkatan kemandirian belajar siswa setelah memperoleh teknik konseling kelompok realitas di SMK Negeri 3 Makassar.

Berdasarkan kesimpulan penelitian di atas, maka diajukan saran sebagai berikut: 1) Kepada para Kepala sekolah, supaya menyediakan kebutuhan yang diperlukan oleh konselor dalam pelaksanaan bimbingan dan konseling agar dalam pelaksanaanya dilapangan dapat berjalan dengan baik. Misalnya, pengadaan ruangan konseling yang memadai, dana, dan konselor yang professional., 2) Kepada Konselor hendaknya lebih intensif dalam melaksanakan kegiatan ini dalam mengantisipasi kecenderungan siswa dalam memandirikan belajarnya di SMK Negeri 3 Makassar.

\section{DAFTAR RUJUKAN}

Hadi, S.2000. Statistik jilid 1 dan 2, Yogyakarta: Andi Offset

Prayitno. 1995. Layanan Bimbingan dan Konseling Kelompok. Ghalia Indonesia

Rina Aristiani, 2006. Keefektifan Layanan Bimbingan Kelompok Dalam Meningkatkan Kemandirian Belajar Siswa Kelas X Sma Negeri 15 Semarang tahun ajaran 2005-2006. Skripsi. Semarang: Unnes.

Romlah, Tatiek, 2001. Bimbingan Kelompok, Malang: UNM

Schunk dan Zimmerman (1998) kemandirian belajar siswa. (Online). http://www.geoogle.com.e-psikologi.

Sugiono. 2008. Metode Penelitian Kuantitatif Kualitataif dan $R \& D$. Bandung: 
132 | Jurnal Psikologi Pendidikan \& Konseling Vol. 1 No. 2 Desember 2015

Sukardi, Dewa Ketut. 1996. Pengantar Tiro, M.A. 2004. Dasar-dasar Statistik. Ujung Pelaksanaan Program BK di sekolah. Jakarta: Rineka Cipta. 